\title{
Effect of harvesting stages on seedling characters of groundnut (Arachis hypogaea L.)
}

ASHVINI PANDIT GAIKWAD*

Department of Agricultural Botany, Disci. Seed Science and Technology, Mahatama Phule Krishi Vidyapeeth, Rahuri, AHMEDNAGAR (M.S.) INDIA

\begin{tabular}{l} 
ARITCLE INFO \\
\hline Received : 26.02 .2014 \\
Accepted $\quad: 25.09 .2014$ \\
\hline KEY WORDS : \\
Groundnut, Root-shoot length and dry \\
matter \\
*Corresponding author: \\
\hline
\end{tabular}

\section{ABSTRACT}

The studies revealed that in seedling characters of groundnut after each harvesting stage tested by carried out germination test in laboratory observed root length $(\mathrm{cm})$, shoot length $(\mathrm{cm})$, dry matter of seedlings $(\mathrm{g})$ were increased after PM in all six varieties of groundnut.

How to view point the article : Gaikwad, Ashwini P. (2014). Effect of harvesting stages on seedling characters of groundnut (Arachis hypogaea L.).Internat. J. Plant Protec., 7(2) : 486-488. 